\title{
Mental Imagery: Motivasi Belajar Siswa dalam Pembelajaran Pendidikan Jasmani
}

\section{Mental Imagery: Students Learning Motivation in Physical Education}

\author{
Boby Agustan ${ }^{1}$, Deri Muhamad Rojikin ${ }^{2}$, Wildan Qohhar ${ }^{3}$ \\ 1,2Prodi PJKR STKIP Muhammadiyah Kuningan, Indonesia \\ ${ }^{3}$ Prodi PJKR STKIP Situs Banten, Indonesia \\ email: bobyagustan@gmail.com¹ \\ do: $:$ https://doi.org/10.20884/1.paju.2021.3.1.4902
}

\begin{abstract}
Abstrak
Penelitian ini dilatarbelakangi kurangnya motivasi siswa dalam menampilkan performa pembelajaran Pendidikan Jasmani. Tujuan penelitian ini adalah untuk meningkatkan motivasi belajar siswa pada pembelajaran penjas melalui metode latihan mental imagery. Penelitian ini merupakan penelitian eksperimen yang dilaksanakan selama 4 minggu dengan intensitas pertemuan satu kali dalam seminggu, total ada 8 kali pertemuan, pada bulan Mei - Juni 2021. Sampel didapat melalui total sampling sebanyak 19 siswa. Data dikumpulkan melalui pretest dan postest. Data dianalisis menggunakan SPSS menggunakan uji T. Hasil penelitian menunjukkan bahwa latihan mental imagery sangat cocok diterapkan pada siswa karena dengan metode latihan mental imagery motivasi belajar siswa dapat meningkat. Karena dengan program latihan mental imagery siswa dapat mengeluarkan kemampuan terbaik. Siswa dapat membayangkan idolanya dalam menampilkan performa saat proses belajar berlangsung. Kesimpulan bahwa metode latihan mental imagery dapat meningkatkan mental siswa sehingga siswa dapat mengeluarkan kemampuan terbaiknya. Pada metode Latihan mental imagery terbukti dapat meningkatkan motivasi belajar siswa. Dengan latihan imagery siswa dapat lebih banyak cara belajar dengan mengandalkan metode lain yaitu dari aspek psikologi.
\end{abstract}

Kata Kunci : Latihan Mental, Mental Imagery, Motivasi Siswa

\begin{abstract}
This research is motivated by the lack of student motivation in displaying the performance of Physical Education learning. The purpose of this study was to increase students' learning motivation in physical education
\end{abstract}

Alamat Koresponden: Prodi PJKR STKIP Muhammadiyah Kuningan

Email: bobyagustan@gmail.com 
learning through mental imagery training methods. This research is an experimental study which was carried out for 4 weeks with the intensity of meeting once a week, a total of 8 meetings, in May - June 2021. The sample was obtained through a total sampling of 19 students. Data were collected through pretest and posttest. The data were analyzed using SPSS using the $T$ test. The results showed that mental imagery training was very suitable to be applied to students because with the mental imagery training method students' learning motivation could increase. Because with the mental imagery training program students can bring out their best abilities. Students can imagine their idol in displaying performance during the learning process. The conclusion is that the mental imagery training method can improve students' mentality so that students can bring out their best abilities. The mental imagery training method is proven to increase students' learning motivation. By practicing imagery, students can learn more ways by relying on other methods, namely from the psychological aspect.

Keywords : Mental Training, Mental Imagery, Student Motivation

\section{PENDAHULUAN}

Salah satu cara untuk meningkatkan mutu pendidikan yaitu dengan memaksimalkan proses pembelajaran didalammnya, tidak terkecuali dalam mata pelajaran Pendidikan Jasmani (Penjas). Pembelajaran Penjas harus meaningfull. Terjadinya interaksi dalam proses pembelajaran antara guru dan anak didik harus memiliki nilai (Agustan, et al.,, 2020; Kusnandar, et al., 2021; Nur et al., 2020). Sedangkan pada realitanya masih banyak pembelajaran yang kurang efektif sehingga tidak tecapainya tujuan pembelajaran. Akibat dari beberapa aspek baik dari penyampaian materi yang tidak maksimal ataupun dari interaksi antara guru dan anak didik yang kurang baik yang menyebabkan rendahnya mutu Penjas (Juliantine, dkk, 2013).

Faktor-faktor penyebab rendahnya mutu pendidikan di Indonesia dalam menampilkan performa anak didik dalam malaksanakan proses belajar meliputi faktor internal maupun faktor eksternal (Subarjah, 2017). Faktor internal meliputi tingkat kecerdasan dan kemampuan awal siswa, motivasi dan minat siswa terhadap suatu pelajaran. Faktor eksternal meliputi lingkungan belajar, sarana dan prasarana pendukung, dosen dan metode pembelajaran (Agustan \& Hidayat, 2021; Latif, et al., 2019). Ada juga penyebab lain diantaranya: siswa tidak memperhatikan guru pada saat guru menjelaskan. Masih ada siswa yang terlambat dalam mengumpulkan tugas pada saat disekolah. Ada siswa tidak menyelesaikan tugas yang diberikan untuk di rumah. 
Boby Agustan \& Deri Muhamad Rojikin | Mental Imagery: Motivasi Belajar Siswa dalam Pembelajaran Pendidikan Jasmani

Siswa sering berdalih izin ke toilet akan tetapi yang terjadi siswa jajan ke kantin, dan siswa sering memainkan handphone pada saat di kelas.

Fenomena tersebut mengindikasikan bahwa siswa memiliki motivasi belajar yang kurang baik atau rendah (Moslem, Komaro, \& Yayat, 2019). Maka dari itu, untuk menjawab permasalahan diatas diperlukan alternatif bentuk pembelajaran lain yaitu dengan latihan mental imagery. Kuan and Roy (2007) menjelaskan bahwa salah satu faktor yang sering berhubungan dengan performa yang baik dalam sebuah proses ajar adalah ketahanan mental dan ketahanan mental tersebut termasuk faktor keterampilan mental.

Merujuk pada pendapat tersebut bahwa ketahanan mental dalam menampilkan performa harus dimiliki oleh masing-masing siswa (Arif, 2013). Siswa yang memiliki ketahanan mental berarti siswa tersebut memiliki keterampilan mental yang baik untuk menghadapi berbagai tantangan yang dihadapi dan memiliki kesadaran akan pentingnya pembelajaran yang di sampaikan oleh gurunya. Lebih lanjut bahwa dalam pembelajaran siswa harus memiliki motivasi belajar yang baik agar siswa dapat menerima materi dari pagi sampai akhrinya pembelajaran (Kamnuron, et al., 2020). Kurangnya motivasi siswa akan pentingnya pembelajaran penjas sehingga menghasilkan proses pembelajaran yang kurang efektif dan kurang tercapainya tujuan dari pembelajaran tersebut.

Berdasarkan fenomena dari rendahnya motivasi belajar, maka guru pendidikan jasmani sebagai orang yang bertanggungjawab bagi peningkatan keterampilan siswa perlu menumbuhkan motivasi belajar yang dimiliki masing-masing siswa atau individu maupun secara kelompok melalui pelatihan mental imagery.

\section{METODE}

Penelitian ini menggunakan metode eksperimen dengan desain penelitian mengunakan pre-experimental jenis one-group pretest-posttest design. Desiain penelitian tertera pada gambar 1. dibawah ini (sugiyono, 2010)

\section{$O_{1} \quad$ X $O_{2}$}

Gambar 1. One-Group Pretest-Posttest Design 
Sampel yang digunakan dalam penelitian ini yaitu sebanyak 19 siswa kelas XI Teknik Komputer Jaringan SMK Yamsik Kuningan. Instrumen penelitian menggunakan angket motivasi siswa (Fitriana, 2016). Analisis data menggunakan aplikasi SPSS versi 21 dengan melakukan Langkah-langah yaitu mentukan Normalitas, Homogenitas dan Uji t.

\section{HASIL}

\section{Uji Normalitas}

Uji normalitas dilakukan untuk menguji apakah semua variabel berdistribusi normal atau tidak. Uji normalitas pada penelitian ini menggunakan metode Kolmogorov- Smirnov, dalam perhitungan menggunakan program SPSS 21. Untuk mengetahui normal tidaknya adalah jika sig.> 0.05 maka normal dan jika sig.< 0.05 dapat dinyatakan data tidak normal. Hasil perhitungan yang diperoleh dapat dilihat pada Tabel 1. dibawah ini.

Tabel 1. Uji Normalitas Hasil Nilai Pre Test dan Post Test

\begin{tabular}{|c|c|c|c|c|}
\hline & \multirow[t]{2}{*}{ Jenis Tes } & \multicolumn{3}{|c|}{ Kolmogorov-Smirnova } \\
\hline & & Statistic & $D f$ & Sig. \\
\hline \multirow{2}{*}{ Skor } & Pretes & , 182 & 19 & ,097 \\
\hline & Postes & , 145 & 19 &, $200^{*}$ \\
\hline
\end{tabular}

Dengan memperhatikan kriteria pengujian di atas tersignifikan uji kolmogrovSmirnov dengan menggunakan program SPSS 21.0 for windows skor semua nilai angket motivasi belajar siswa pretest dan posttest lebih besar dari 0,05,maka dapat disimpulkan data berdistribusi normal.

\section{Uji Homogenitas}

Uji homogenitas dilakukan dengan mengunakan uji statistik descriptive SPSS, jika hasil analisis menunjukkan nilai $p>$ dari 0.05 , maka data tersebut homogen, akan tetapi jika hasil analisis data menunjukkan nilai $p<$ dari 0.05 , maka data tersebut tidak homogen. Hasil perhitungan dapat dilihat pada Tabel 2. dibawah ini.

Tabel 2. Uji Homogenitas Data Nilai Pre Test dan Post Test

\begin{tabular}{cccc}
\hline Levene Statistic & $\mathrm{df1}$ & $\mathrm{df2}$ & Sig. \\
\hline, 789 & 1 & 36 &, 380 \\
\hline
\end{tabular}


Boby Agustan \& Deri Muhamad Rojikin | Mental Imagery: Motivasi Belajar Siswa dalam Pembelajaran Pendidikan Jasmani

Berdasarkan hasil output uji homogenitas dua variansi dengan menggunakan uji levene dengan menggunakan program SPSS 21.0 for windows, pada tabel diatas menunjukan bahwa nilai pretest postest semua nilai tersignifikasi lebih besar dari 0,05 diterima,maka dapat disimpulkan bahwa tidak terdapat perbedaan variansi antara nilai pretest dan postest (Homogen).

\section{Uji Paired Sample T - Test}

Pengolahan data dilakukan dengan menggunakan statistik program software komputer Stastistical Product and Service Solution (SPSS) 21. Pengujian hipotesis menggunakan uji paired sample t-test. Hasil uji hipotesis dapat dilihat pada tabel 3 dibawah ini.

Tabel 3. Uji Hipotesis Data Nilai Pre Test dan Post Test

\begin{tabular}{|c|c|c|c|c|c|c|c|c|c|}
\hline & & \multicolumn{5}{|c|}{ Paired Differences } & \multirow{4}{*}{$\mathrm{T}$} & \multirow{4}{*}{$f$} & \multirow{4}{*}{$\begin{array}{l}\text { Sig (2- } \\
\text { tailed) }\end{array}$} \\
\hline & & \multirow{3}{*}{ Mean } & \multirow{3}{*}{$\begin{array}{l}\text { Std.Devi } \\
\text { ation }\end{array}$} & \multirow{3}{*}{$\begin{array}{l}\text { Std.error } \\
\text { mean }\end{array}$} & $95 \%$ & confidence & & & \\
\hline & & & & & $\begin{array}{l}\text { interval } \\
\text { Difference }\end{array}$ & of the & & & \\
\hline & & & & & Lower & Upper & & & \\
\hline & PRETEST & & & & & & & & \\
\hline \multirow[t]{2}{*}{ Pair 1} & - & $-20,94$ & 3,20 & ,735 & $-22,492$ & $-19,402$ & $-28,485$ & 18 &, 000 \\
\hline & POSTEST & & & & & & & & \\
\hline
\end{tabular}

Berdasarkan tabel dari uji paired samples t-test hasil nilai pembelajaran mental imagery menggunakan aplikasi SPSS Versi 21. Hasil uji paired sample t-test data, nilai menunjukkan sig.(2-Tailed). Itu dapat terlihat dari hasil sig.(2-Tailed) bernilai 0,000. Yang berarti bahwa hasil dari nilai tersebut terdapat pengaruh latihan mental imagery terhadap motivasi belajar siswa di kelas XI Teknik Komputer Jaringan SMK Yamsik Kuningan.

\section{PEMBAHASAN}

Berdasarkan analisis data penelitian diperoleh peningkatan yang signifikan terhadap kelompok yang diteliti. Pemberian perlakuan latihan imagery selama 16 kali pertemuan memberikan pengaruh terhadap peningkatan motivasi belajar siswa pada pembelajran penjas di kelas 11 TKJ SMK Yamsik Kuningan,yaitu sebesar 394. Hal 
tersebut sesuai dengan teori bahwa pelatihan imagery bertujuan untuk meningkatkan kemampuan psikologis siswa yang dilakukan sebanyak 16 kali pertemuan.

Imagery adalah proses kognitif paling dasar untuk menghasilkan tindakan motorik dan teknik peningkatan kinerja (Cumming \& Williams, 2012). Latihan imagery memilki keunggulan dalam menguatkan mental anak didik dalam proses pembelajaran. Proses ajar yang identik dengan interaksi antara anak didik dan guru sangat mempengaruhi kualitas atau output yang diinginkan (Carsiwan, 2016). Selain itu, metode latihan Imagery merupakan bagian integral dari keseluruhan keterampilan psikologis (Arif, 2013). Hal ini akan mempengaruhi kematangan psikologi anak didik dalam menerima materi pelajaran.

Ketika siswa membayangkan atau memvisualisasikan secara gamblang saat sedang belajar dan membayangkan dirinya menunjukan penampilan sempurna. Kegiatan tersebut sebenarnya mengirim implus saraf yang halus dari otak ke otot yang terlibat dalam kegiatan tersebut ketika siswa membayangkan keberhasilan secara berurutan terjadilah proses belajar yang sebenarnya dan pemain tersebut telah menggoreskan gambaran tepatnya gerakan tubuh yang seharusnya terjadi,sehingga dapat mencapai pembelajaran yang optimal.

Hal ini diperkuat dengan pendapat (Komarudin, 2016) bahwa latihan imagery sangat efektif untuk meningkatkan performa,bahkan 90-97\% pemain propesionalpun menggunakan latihan imagery karena latihan tersebut sangat bermanfaat untuk meningkatkan performanya. Siswa melakukan imagery dengan berbagi tujuan ada yang berlatih untuk tujuan belajar keterampilan,mengembangkan strategi,mempersiapkan mental sebelum kompetisi,mengembangkan keterampilan mental,mengatasi stres dan rintangan dalam olahraga baik itu cedera,latihan berat dan gangguan gangguan lainnya.

Memperoleh rata rata hasil angket pretest sesbesar 1054 dan Postest sebesar 1448 terdapat peningkatan sebesar 394.Berdasarkan hasil uji yang dilakukan SPSS 21.0 for windows menunjukan data berdistribusi normal,bervariansi homogen, dan hasil uji $t$ posttest menunjukan :1. Terdapat peningkatan terhadap motivasi belajar siswa pada pembelajaran penjas; 2 . Terdapat pengaruh latihan mental terhadap motivasi belajar siswa pada pembelajaran Penjas.

\section{SIMPULAN}

Berdasarkan penelitian yang telah diperoleh maka dapat ditarik kesimpulan adanya pengaruh yang signifikan dari latihan imagery terhadap peningkatan motivasi belajar siswa 
Boby Agustan \& Deri Muhamad Rojikin | Mental Imagery: Motivasi Belajar Siswa dalam Pembelajaran Pendidikan Jasmani

pada pembelajaran penjas di kelas 11 TKJ SMK Yamsik Kuningan, yang dibuktikan dengan adanya peningkatan skor tes awal dengan tes akhir. Latihan imagery dapat menjadi salah satu alternatif bagi guru dan pelatih untuk meningkatkan motivasi belajar dan belatih baik siswa maupun atlet.

\section{DAFTAR PUSTAKA}

Agustan, B., \& Hidayat, A. R. (2021). Play Teach Play: Pengaruhnya Terhadap Kemampuan Passing Futsal. Physical Activity Journal, 2(2), 159. https://doi.org/10.20884/1.paju.2021.2.2.3875

Agustan, B., Kusmaedi, N., Hendrayana, Y., Abduljabar, B., \& Ginanjar, A. (2020). Modifikasi pembelajaran: hybrid sport education-invasion games competence model terhadap performa permainan bola basket. Jurnal SPORTIF : Jurnal Penelitian Pembelajaran, 6(1), 157-172. https://doi.org/10.29407/js_unpgri.v6i1.14005

Carsiwan. (2016). Penerapan latihan imagery mental dalam pelatihan olahraga unggulan di provinsi jawa barat. Jurnal Kepelatihan Olahraga, 8(1), 1-20.

Cumming, J., \& Williams, S. E. (2012). The Role of Imagery in Performance. The Oxford Handbook of Sport and Performance Psychology, (June), 213-232. https://doi.org/10.13140/2.1.3274.5925

Fitriana, E. (2016). Hubungan Antara Motivasi Belajar Dengan Hasil Belajar IPS Siswa Kelas IV SDN Di Gugus Dr. Soetomo Kecamatan Blado Batang. 180.

Juliantine, T., Subroto, T., \& Yudiana, Y. (2013). Model-model Pembelajaran Pendidikan Jasmani. Bandung: FPOK UPI Bandung.

Kamnuron, A., Hidayat, Y., \& Nuryadi, N. (2020). Perbedaan Kepercayaan Diri Pada Siswa yang Mengikuti Ekstrakurikuler Olahraga. Physical Activity Journal. https://doi.org/10.20884/1.paju.2020.1.2.2394

Komarudin. (2016). Penilaian Hasil Belajar Pendidikan Jasmani dan Olahraga. Bandung: PT Remaja Rosdakarya.

Kuan, G., \& Roy, J. (2007). Goal profiles, mental toughness and its influence on performance outcomes among Wushu athletes. Journal of Sports Science and Medicine, 6(CSSI-2), 28-33.

Kusnandar, Friskawati, G. F., Kharisman, V. A., \& Budi, D. R. (2021). Elementary Student's Physical Activity during Pandemic Covid 19. Annals of Tropical Medicine \& Public Health, 24(03), 10-16. https://doi.org/10.36295/asro.2021.24329

Latif, M., Faozi, F., Bakhri, R. S., Harja, F., \& Listiandi, A. D. (2019). Pengaruh Permainan 
Tradisional Terhadap Minat Siswa Dalam Kegiatan Pembelajaran Pendidikan Jasmani, Olahraga, Dan Kesehatan Di Sman 1 Cikembar. Physical Activity Journal, 1(1), 82. https://doi.org/10.20884/1.paju.2019.1.1.2005

Lukman Arif, P. (2013). Pengaruh Mental Imagery Terhadap Kemampuan Siswa Dalam Penguasaan Teknik Dasar Dribble Bola Basket Dalam Pembelajaran Pendidikan Jasmani Olahraga Dan Kesehatan. Jurnal Pendidikan Olahraga Dan Kesehatan, 1(1), 13-16.

Lukman Arif, P. (2013). Pengaruh Mental Imagery Terhadap Kemampuan Siswa Dalam Penguasaan Teknik Dasar Dribble Bola Basket Dalam Pembelajaran Pendidikan Jasmani Olahraga Dan Kesehatan. Jurnal Pendidikan Olahraga Dan Kesehatan, 1(1), 13-16.

Moslem, M. C., Komaro, M., \& Yayat. (2019). Faktor-Faktor Yang Menyebabkan Rendahnya Motivasi Belajar Siswa Dalam Mata Pelajaran Aircraft Drawing Di Smk. Journal of Mechanical Engineering Education, 6(2), 258-265. https://doi.org/10.17509/jmee.v6i2.21803

Nur, L., Malik, A. A., Juditya, S., Kastrena, E., Widyawan, D., Agustan, B., ... Yang, C. B. (2020). Comparison of two types of instruction in physical education. International Journal of Psychosocial Rehabilitation, 24(10), 1785-1793. https://doi.org/10.37200/IJPR/V24I10/PR300205

Subarjah, H. (2017). Hasil Belajar Keterampilan Bermain Bulutangkis Studi Eksperimen Pada Siswa Diklat Bulutangkis FPOK-UPI. Jurnal Cakrawala Pendidikan. https://doi.org/10.21831/cp.v3i3.361

sugiyono. (2010). Metode Penelitian Kuantitatif \& kualitatif. Journal of Experimental Psychology: General. 